\title{
CHLOROQUINE ACCUMULATION AND ALTERATIONS OF PROTEOLYSIS AND PINOCYTOSIS IN THE RAT CONCEPTUS IN VITRO
}

\author{
JeFrRey L. Ambroso and Craig Harris* \\ Toxicology Program, Department of Environmental and Industrial Health, University of Michigan, \\ Ann Arbor, MI, U.S.A.
}

(Received 2 June 1993; accepted 17 September 1993)

\begin{abstract}
The teratogenicity of chloroquine (CQ) has been hypothesized to result from its effects on lysosomal function, specifically the ability of the visceral yolk sac (VYS) to capture and degrade external macromolecules. Using the rat whole embroyo culture system, we evaluated the ability of $\mathrm{CQ}$ to accumulate in conceptal tissues and its effects on aspects of VYS function known to be important in the uptake and processing of nutrients. When CQ was added directly to the culture medium, it was found to accumulate rapidly in conceptal tissues, particuarly the VYS. Tissue concentrations of CQ in the embryo proper reached approximately 10 -fold those in the medium, whereas concentrations in the VYS exceeded by 100 -fold the medium concentration within a 4-hr exposure on gestational day (GD) 10. Embryotoxic concentrations of $\mathrm{CQ}(10-30 \mu \mathrm{M})$ enhanced the activity of lysosomal cysteine proteinases measured in vitro under optimum $\mathrm{pH}$ conditions in both embryonic and VYS homogenates after a 26-hr treatment from GD 10-11. A different pattern of response in enzyme activity was observed between embryos and VYSs that could be attributed to the preferential accumulation of $C Q$ in the VYS. Nonembryotoxic concentrations of CQ (1-7.5 $\mu \mathrm{M})$ induced a concentration-dependent incrcasc in VYS enzyme activity that peaked in conceptuses exposed to $20 \mu \mathrm{M} \mathrm{CQ}$ (an intermediate embryotoxic concentration). The enhanced cysteine proteinase activity was time dependent and appeared to increase gradually in conceptuses exposed to $10-20 \mu \mathrm{M}$ CQ during the $26-\mathrm{hr}$ culture period. This was in contrast to the rapid accumulation of $C Q$ in conceptal tissues seen on gestational day 10 . Protein content in the VYS was increased significantly after a 9-hr exposure of whole conceptuses to CQ $(20 \mu \mathrm{M})$, indicating an inhibition of VYS proteolytic activity in situ. After $24 \mathrm{hr}$ of exposure to $20 \mu \mathrm{M} \mathrm{CQ}$, VYS protein content was not significantly different from control, but embryonic protein was reduced significantly by $20 \%$. These observations are consistent with a model of reversible inhibition of VYS proteolysis by $\mathrm{CQ}$ followed by a compensatory increase in lysosomal proteinase activity. VYS fluid-phase pinocytosis was also assessed after $C Q$ exposure and found to be inhibited only in the highest CQ concentration tested $(30 \mu \mathrm{M})$. Lower concentrations of $\mathrm{CQ}$ that were still embryotoxic $(10-20 \mu \mathrm{M})$ did not affect VYS fluid-phase pinocytosis, suggesting that inhibition of this activity is not primarily responsible for CQ embryotoxicity.
\end{abstract}

Key words: chloroquine; cysteine proteinases; histiotrophic nutrition; embryotoxicity

Chloroquine (CQ) $\dagger$, an antimalarial drug, has been shown to be an in vivo teratogen in rodent and avian species [1-3], and at least one case report associates high dosages of CQ with human embryotoxicity [4]. Our recent work demonstrates that relatively low concentrations of CQ $(10-30 \mu \mathrm{M})$ are embryotoxic to organogenesis-stage rat conceptuses grown in vitro, suggesting that direct effects of the drug on the conceptus could be responsible for the in vivo embyrotoxicity, rather than changes in the maternal

\footnotetext{
* Corresponding author: Dr. Craig Harris, Toxicology Program, Department of Environmental and Industrial Health, The University of Michigan, 1420 Washington Hts., Ann Arbor, MI 48109-2029. Tel. (313) 936-3397; FAX (313) 763-8095.

$\dagger$ Abbreviations: CQ, chloroquine; VYS, visceral yolk sac; GD, gestational day; Z-Phe-Arg-7AMC, benzyloxycarbonyl - phenylalanine - arginine - 7 - amino - 4 methyl-coumarin; Z-Phe-Ala-CHN ${ }_{2}$, benzyloxycarbonylphenylalanine-alanine-diazomethylketone; PRIM, primaquine; FITC-dextran, fluorescein isothiocyanate-conjugated dextran; E-64, trans-epoxysuccinyl-leucylamido(4guanidino)-butane; and MA, methylamine.
}

system [5]. The actual cellular or molecular mechanisms by which $\mathrm{CQ}$ might produce embryotoxicity have not been investigated, although several authors have proposed that the ability of $\mathrm{CQ}$ to inhibit DNA repair accounts for the deleterious effects resulting from interaction between $\mathrm{CQ}$ and other teratogens $[3,6]$.

In contrast to the limited data available regarding the mechanisms of CQ embryotoxicity, substantial literature exists concerning the effects of the drug on mammalian cells in vitro. A large proportion of this work has focused on the function of the cellular vacuolar system because $\mathrm{CQ}$ is known to affect endocytosis, exocytosis and lysosomal function. $\mathrm{CQ}$ also has the ability to inhibit the processes of DNA synthesis and repair in cell-free systems [7]. The main effect of low concentrations of CQ (and related alkylamines) on mammalian cells, however, is generally agreed to be an increased $\mathrm{pH}$ of the normally acidic intracellular vacuoles (endosomes and lysosomes) resulting in changes in vesicular transport and enzymatic activity [for review, see Refs. 8 and 9]. Ohkuma and Poole [10] have 
demonstrated that adding $\mathrm{CQ}$ to the medium of cultured macrophages rapidly and reversibly increases lysosomal $\mathrm{pH}$. Increased vacuolar $\mathrm{pH}$ is believed to result from the trapping of $\mathrm{CQ}$ in these acidic organelles. The nonionized form of the compound readily diffuses across cell membranes at physiological $\mathrm{pH}$, becoming ionized to a membraneimpermeant form within acidic compartments. Thus, protons are removed as the drug accumulates in acidic vacuoles, leading to an increased $\mathrm{pH}$ as vacuolar buffering capacity is exceeded. Vacuolar swelling occurs due to the osmotic effect of high concentrations of the weak base in these compartments, and possibly also from the accumulation of substrates such as proteins whose digestion by acid hydrolases is inhibited by $\mathrm{CO}$.

A common finding in studies of CQ-treated cells is an intracellular accumulation of protein resulting from decreased proteolytic degradation of endocytosed exogenous proteins [11-13]. This effect has typically been attributed to inhibition of lysosomal proteolysis by $\mathrm{CQ}$, due to either increased lysosomal $\mathrm{pH}$ or possibly the direct inhibitory effects of the drug on proteinases [14]. Indeed, susceptibility of cellular hydrolytic capacity to inhibition by $\mathrm{CQ}$ and related compounds has usually been taken as evidence of lysosomal involvement. There is also evidence, however, to support the idea that CQ can inhibit vacuolar trafficking [15] and block receptor recycling [16]. The cellular effects of $\mathrm{CQ}$, therefore, include alterations in the normal intracellular uptake, trafficking, degradation and secretion of several macromolecules. These changes in the function of the cellular vacuolar system in various cell types in vitro, together with the reported ability of $\mathrm{CQ}$ to inhibit endocytosis and lysosomal proteolysis in the cultured GD 17 rat VYS [17], suggest that the mechanism of $\mathrm{CQ}$ embryotoxocity might involve the inhibition of VYS-mediated nutritional function during organogenesis. This function depends upon the capacity of the VYS endoderm epithelium to endocytose and degrade exogenous proteins and is essential for embryonic growth during this sensitive period of development $[18,19]$. The evidence indicates that VYS-mediated nutrition is a target for several embryotoxicants that affect this pathway [for review, see Ref. 20].

Previous work in this laboratory has implicated the VYS endoderm epithelium as a main target for $\mathrm{CQ}$, although we suspect that the embryo proper might also be directly affected [5]. At medium concentrations of $30 \mu \mathrm{M}, \mathrm{CQ}$ increased VYS protein content even though the DNA content of the same tissue decreased. This treatment also produced an accumulation of eosinophilic material (presumably protein) in cytoplasmic vacuoles of the VYS epithelium, the normal site of degradation of exogenous protein endocytosed by these cells [21]. Such findings are characteristic of lysosomal dysfunction and suggest that $\mathrm{CQ}$ may inhibit lysosomal proteolysis in the VYS endoderm, the process which the embryo relies upon for its amino acid supply. The lysosomal cysteine proteinases cathepsin B and cathepsin L have been implicated as being responsible for VYS proteolysis, mainly because of the ability of leupeptin to inhibit this process $[22,23]$.

The objective of the present study was to investigate the ability of $\mathrm{CQ}$ to accumulate in conceptal tissues and inhibit several aspects of VYS nutritional function believed to be important for embryonic nutrient supply during organogenesis. These parameters include the activities of conceptal lysosomal cysteine proteinases (cathepsin B and cathepsin L) and fluid phase endocytosis. This report provides data to support the idea that $\mathrm{CQ}$ embryotoxicity results from accumulation of the drug in conceptal tissues with subsequent alterations of VYS (and possibly embryonic) vacuolar systems.

\section{MATERIALS AND METHODS}

Chemicals. The cysteine proteinase substrate ZPhe-Arg-7AMC, 7AMC standard and the cysteine proteinase inhibitor were obtained from Bachem Bioscience Inc., Philadelphia, PA. Chloroquine diphosphate, PRIM, FITC-dextran, MA and E-64 were obtained from the Sigma Chemical Co., St Louis, MO. All other reagents were of the highest quality commercially available.

Animals. Time-mated primigravida SpragueDawley rats were obtained from the Reproductive Sciences Program Small Animal Core Facility, the University of Michigan, on GD 7-9. The morning following copulation, as indicated by a sperm positive vaginal smear, was designated as GD 0 . Pregnant animals were maintained on a 14-hr light/10-hr dark cycle and given free access to Purina Rat Chow (Ralston Purina) and water until the morning of explantation.

Embryo culture. On the morning of GD 10 , pregnant dams were anesthetized with ether and exsanguinated via the abdominal aorta. The blood was centrifuged and the serum heat-inactivated and stored at $-20^{\circ}$ for subsequent use in culture medium. Uteri were removed from the dams and placed in warmed Hanks' Balanced Salt Solution (HBSS, Gibco BRL, Gaithersburg, MD), and the implantation sites were dissected free. Conceptuses were removed carefully from the decidual mass, and Reichert's membrane was opened to allow the embryo to develop properly in culture. Conceptuses were placed in $125-\mathrm{mL}$ roller bottles containing $33 \%$ heat-inactivated female rat serum in HBSS supplemented with penicillin $G(100 \mathrm{IU} / \mathrm{mL})$ and streptomycin $(50 \mu \mathrm{g} / \mathrm{mL})$. The medium had been $\begin{array}{lllll} & \text { warmed to } 37^{\circ} \text { and gassed with } 20 \% & \mathrm{O}_{2} / 5 \% & \mathrm{CO}_{2} /\end{array}$ $75 \% \mathrm{~N}_{2}$ prior to addition of conceptuses. Less than ten conceptuses/bottle were cultured in a total volume of $15 \mathrm{~mL}$ culture medium. The bottles were sealed and placed in a roller incubator overnight and then were regassed with $95 \% \quad \mathrm{O}_{2} / 5 \% \mathrm{CO}_{2}$ on the morning of GD 11. For DNA, protein, and enzyme assays, whole conceptuses were removed from the culture medium at various times and rinsed three times in HBSS. The embryos and VYSs were dissected apart and placed individually in enough sodium phosphate buffer $(50 \mathrm{mM}, 1 \mathrm{mM}$ EDTA, $\mathrm{pH}$ 6.0) to produce a homogenate of $200-300 \mu \mathrm{g}$ protein $/ \mathrm{mL}$. The tissues were disrupted ultrasonically and frozen at $-70^{\circ}$ prior to the protein assays. 
Cathepsin $B$ and $L$ activity was determined after the same tissue was taken through a second freeze-thaw and briefly centrifuged to remove insoluble material.

Exposure. Stock CQ solutions of $15 \mathrm{mg} / \mathrm{mL}$ were prepared fresh in sterile HBSS, $\mathrm{pH}$ 7.4. The stock or vehicle (total volume of $15 \mu \mathrm{L}$ or less) was added directly to the culture medium immediately prior to the addition of conceptuses on the morning of GD 10 , and exposure was continuous throughout the culture period.

Protein and DNA assays. Protein content was determined by the method of Bradford [24], using bovine gamma globulin standard and dye reagent supplied by Bio-Rad (Richmond, CA). The assay was modified for microtiter plate assay as described by Stark $e t$ al. [25]. DNA content was determined spectrofluorometrically by the method of Labarca and Paigen [26], using bovine DNA as a standard.

Chloroquine extraction and determination. To estimate CQ concentrations present in conceptal tissues exposed to the drug in whole embryo culture, an adaptation of the method of Adelusi and Salako [27] was employed. This assay utilizes an ether extraction of CQ from a basic solution with back extraction into acid after two wash steps. The fluorescence of the extracted CQ is then read in a buffered medium at $\mathrm{pH} 9.5$ with excitation and emission set to 331 and $386 \mathrm{~nm}$, respectively. The second wash step, designed to remove metabolites, was omitted from our assay since it was found to have no effect upon our determination of CQ content in tissues as calculated from authentic CQ standards extracted concurrently. The assay was sensitive enough to detect low micromolar concentrations of $\mathrm{CQ}$, so that determinations could be made on individual embryos and VYSs. Untreated control tissues consistently gave readings equivalent to the zero standard while recovery of $\mathrm{CQ}$ from spiked tissue samples approached $90 \%$. To calculate original tissue concentrations, a factor was determined in order to take into account the volume of the tissue extracted. Measurements of tissue wet weight were therefore performed on control tissues (tissues were dissected in HBSS, held gently between watchmakers forceps, and any excess water was blotted; the blotted tissues were placed into preweighed microcentrifuge tubes and then reweighed, from which the tissue wet weight was determined). It was assumed that (1) the tissue density was $1.0 \mathrm{~g} / \mathrm{mL}$; and (2) the volume of the treated tissues was equal to that of the controls.

Cathepsin $B$ and $L$ activity. The combined hydrolytic activity of the lysosomal cysteine proteinases cathepsin $B$ and cathepsin $L$ was determined using the fluorometric substrate Z-Phe-Arg-7AMC. Both enzymes can hydrolyze this substrate effectively [28], and both have been implicated as likely targets for proteinase inhibitors in the rat VYS [22,29]. Aliquots of the tissue homogenates were diluted and used as the enzyme source. The assay was a slight modification of the method of Barrett and Kirschke [28] for cathepsin L, substituting $0.1 \%$ Triton X-100 for the Brij 35 diluent used in the original assay and determinations were made at $37^{\circ}$ rather than $30^{\circ}$. All other conditions were as originally described. Since Z-Phe-Arg-7AMC can also be hydrolyzed by some trypsin-like enzymes, it was important to demonstrate that the enzyme activity present in our homogenates was due to lysosomal cysteine proteinases. Experiments showed that the activity present in our samples was latent (activated by freeze-thaw), enhanced at low $\mathrm{pH}$ and in the presence of sulfhydryl reducing agents (data not shown) as well as being strongly inhibited by specific inhibitors of cathepsins B and L such as E-64 and the peptidyl diazomethylketones (see Fig. 2 and Results). These properties are characteristic of lysosomal cysteine proteinases $[28,30]$.

Grubb et al. [31] have studied the ontogeny of lysosomal cysteine proteinase activity in the rat VYS during the second half of gestation and found two enzymes capable of hydrolyzing Z-Phe-Arg-7AMC, presumably cathepsins $B$ and $L$. Their data show that GD 12.5 VYSs possess very low cathepsin B activity compared with cathepsin L activity. In the present study, we have not distinguished between these two closely related enzymes, but further characterization studies indicate that the activity measured in our assay is also mainly due to cathepsin L.*

Pinocytosis assay. Fluid-phase pinocytosis was assayed by exposing viable conceptuses in culture to an FITC-dextran polymer for various time periods after which the amount of FITC fluorescence accumulated by the VYS was measured spectrofluorometrically. FITC-dextrans are known to accumulate in the lysosomal compartment and have been used as tracers of fluid-phase pinocytosis in various systems $[32,33]$. We have found that accumulation of FITC fluorescence by the VYSs of viable conceptuses exposed to FITC-dextrans is characteristic of fluid-phase marker uptake in the rat VYSs as defined by Duncan and Lloyd [34], being linear with respect to time, partially inhibited by colchicine, and completely inhibited by incubation at $4^{\circ}$ (data not shown). Another characteristic of fluid-phase pinocytosis observed in conceptuses incubated with FITC-dextran is that only the VYS (not the embryo proper) accumulates FITC fluorescence. In addition, fluorescent microscopy of VYSs exposed to FITC-dextran has confirmed that FITC-fluorescence is localized within discrete vacuoles in the cytoplasm of the VYS cndoderm epithelium (not shown).

Conceptuses exposed to culture medium containing $10 \mu \mathrm{M}$ FITC-dextran for various times were removed from culture, rinsed four times in ice-cold $0.9 \%$ $\mathrm{NaCl}$ and their VYSs dissected free. Individual VYSs were then placed in $0.5 \mathrm{~mL}$ HBSS and ultrasonically disrupted. An aliquot of the resulting homogenate was saved for protein determination. Another $250-\mu \mathrm{L}$ aliquot was added to an equal volume of $0.1 \%$ Triton $\mathrm{X}-100$ and mixed. This mixture was diluted with $2 \mathrm{~mL}$ of $50 \mathrm{mM}$ sodium phosphate buffer, $\mathrm{pH} 7.4$, and fluorescence was measured at FITC wavelengths (excitation $495 \mathrm{~nm}$; emission $520 \mathrm{~nm}$ ). Arbitrary fluorescence units were corrected for background fluorescence of VYSs not exposed to the dextran and normalized to the protein content of each respective VYS. By also assaying the fluorescence

\footnotetext{
* Ambroso JL and Harris $\mathrm{C}$, unpublished results.
} 
Table 1. Chloroquine accumulation in conceptal tissues following exposure in whole embryo culture

\begin{tabular}{lcc}
\hline \multicolumn{1}{c}{ Treatment* $^{*}$} & $\begin{array}{c}\text { Chloroquine } \\
\text { extracted } \\
(\mu \mathrm{g})\end{array}$ & $\begin{array}{c}\text { Tissue chloroquine } \\
\text { concentration } \\
(\mathrm{mM})\end{array}$ \\
\hline $\begin{array}{l}4 \mathrm{hr} \\
\text { Day 10 embryo }\end{array}$ & $0.2 \pm 0.0$ & $0.3 \pm 0.1(6)$ \\
Day 10 yolk sac & $1.7 \pm 0.4$ & $5.6 \pm 1.2(6)$ \\
Day 10 whole embryo & $2.6 \pm 0.6$ & $1.4 \pm 0.3(3)$ \\
26 hr & $1.0 \pm 0.3$ & $0.4 \pm 0.1(4)$ \\
Day 11 embryo & $4.7 \pm 0.7$ & $4.6 \pm 0.6(7)$ \\
Day 11 yolk sac & $7.4 \pm 0.5$ & $0.8 \pm 0.1(3)$ \\
Day 11 whole embryo & & \\
\hline
\end{tabular}

* Initial concentrations of $30 \mu \mathrm{M}$ chloroquine were added directly to the culture medium at the start of the culture period (GD 10). After a 4- or 26-hr incubation, conceptuses were removed from the culture medium, rinsed twice in HBSS, and either dissected to embryos and VYSs or left intact.

$\uparrow$ Chloroquine was extracted from individual tissues, as described in Materials and Methods. Data represent means \pm SD

$\ddagger$ Concentrations were calculated based on the volume of control tissues, as described in Materials and Methods. Data are means \pm SD of $(N)$ samples from three separate experiments.

present in the culture medium it is possible to calculate an Endocytic Index, which represents the amount of culture medium cleared of the tracer molecule per mg VYS protein per hour [35]. Using this procedure, an Endocytic Index of approximately $3.0 \mu \mathrm{L} / \mathrm{mg} / \mathrm{hr}$ can be calculated for GD 11 VYSs exposed to the 40-kDa FITC-dextran. This value is within the range of published endocytic indices for rat VYS using radiolabeled substrates.

Statistical analysis. The statistical software package Statview (Abacus Concepts, Inc., 1986) was used to analyze enzyme activity data and Endocytic Index data. One-way analysis of variance was used to determine overall differences between multiple treatment groups. This was followed by the Scheffe test for multiple comparisons of differences between individual treatment means. Where only one treatment group was present (Figs. 3 and 5), the data were analyzed using an unpaired $t$-test to compare two means at particular time points.

\section{RESULTS}

The ability of rat conceptuses to accumulate $\mathrm{CQ}$ from the culture medium was assessed by acid extraction of CQ from conceptal tissues, as described in Materials and Methods. The data in Table 1 illustrate that both embryos and VYSs of conceptuses exposed to $\mathrm{CQ}$ attain concentrations of $\mathrm{CQ}$ much greater than those present in the culture medium. This is particularly true of the VYS. Tissue concentrations estimated after a 26-hr exposure to $30 \mu \mathrm{M}$ CQ $(0.4 \mathrm{mM}$ in the embryo; $4.6 \mathrm{mM}$ in the VYS) were not substantially different from those determined after $4 \mathrm{hr}$ of exposure $(0.3 \mathrm{mM}$ in the embryo and $5.6 \mathrm{mM}$ in the VYS). It should be noted that the use of control tissue wet weights to calculate $\mathrm{CQ}$ concentrations in treated tissues may overestimate the $\mathrm{CQ}$ concentration because $\mathrm{CQ}$ causes cytoplasmic swelling and likely increases tissue volume. Some of this effect, however, may be compensated for by decreased overall growth observed in CQ-treated conceptuses.

As observed previously [5], CQ exposure throughout a 26 -hr embryo culture period elicited a differential response between embryos and VYSs in terms of protein content (Fig. 1A). Embryonic protein content showed a concentration-dependent decrease (to $57 \%$ of control at $30 \mu \mathrm{M}, \mathrm{P}<0.001$ ), whereas VYS protein content showed an inverse concentration-response relationship, being decreased only in the $10 \mu \mathrm{M}$ treatment group (85\% of control, $P<0.05$ ). VYS protein content was decreased slightly by $20 \mu \mathrm{M}$ CQ treatment $(91 \%$ of control, not significant) but was increased significantly in conceptuses in the $30 \mu \mathrm{M}$ CQ group $(126 \%$ of control, $\mathrm{P}<0.001)$. This contrasts sharply with the observed concentration-dependent decrease in DNA content of both embryos and VYSs in the same conceptuses (Fig. 1B).

The combined activities of cathepsins $B$ and $L$ in GD 11.5 conceptuses cultured in the presence of $\mathrm{CQ}$ are also presented in Fig. 1. Panels $C$ and $D$ show this activity normalized to either protein or DNA content, respectively. A comparison of these panels indicates that the traditional normalization of enzyme activity to protein content underestimated VYS cathepsin activity in the 20 and $30 \mu \mathrm{M}$ treatment groups because of the abnormal accumulation of protein in VYSs at these higher concentrations. In the $10 \mu \mathrm{M}$ group, however, normalization of enzyme activity to either protein or DNA content resulted in little change in activity with reference to control (333 vs $337 \%$ of control, respectively). Subsequent enzyme activities, therefore, are presented normalized to DNA content for tissues exposed to CQ concentrations greater than $10 \mu \mathrm{M}$.

As expected, cathepsin B and L activities in the 
A.

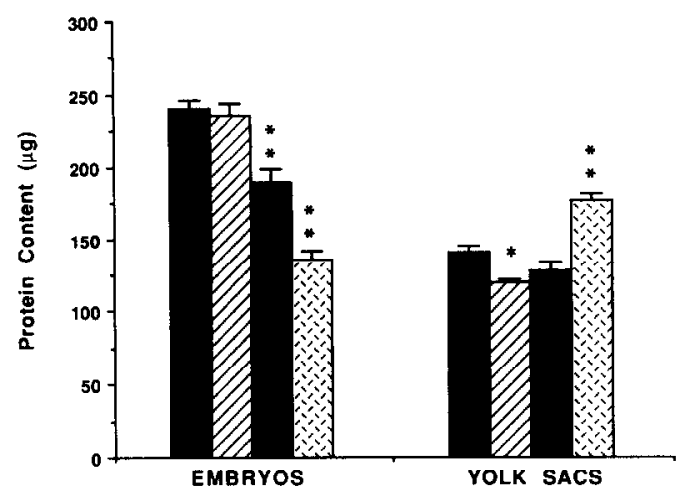

C.

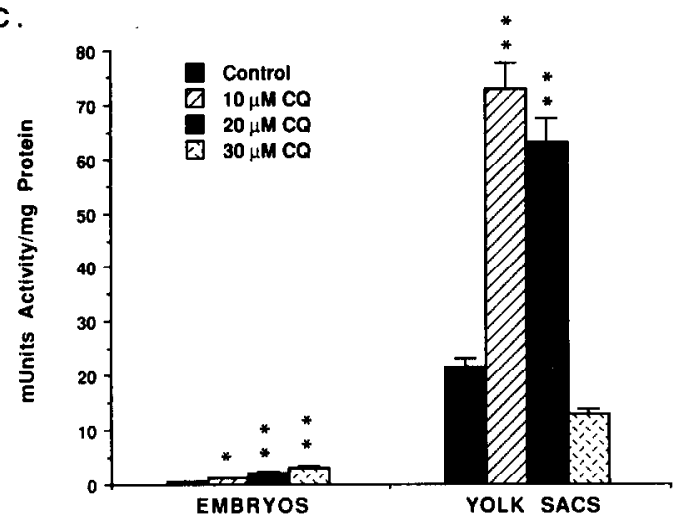

B.

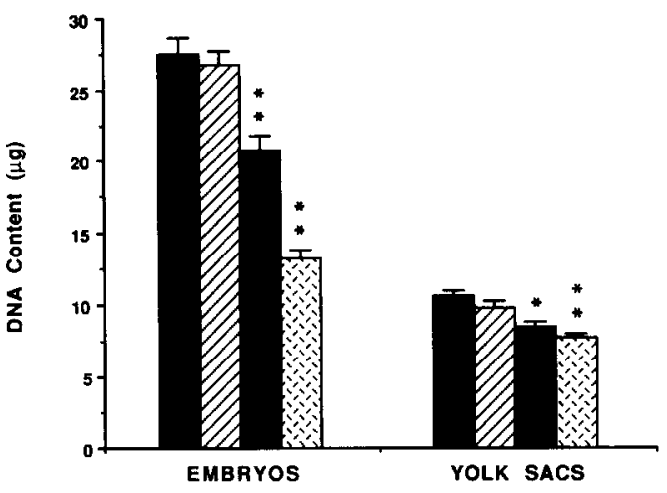

D.

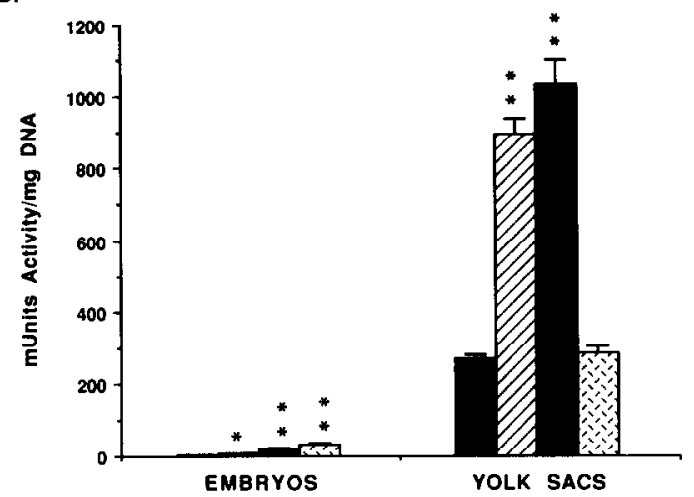

Fig. 1. Protein content (A), DNA content (B) and cathepsin B and $L$ activity normalized to protein (C) and DNA (D) content of conceptal tissues at the end of a 26-hr culture period (GD 11.5). Mean embryonic enzyme activity was $0.5,1.2,2.2$ and $3.2 \mathrm{mU} / \mathrm{mg}$ protein and $4,10,20$, and $32 \mathrm{mU} / \mathrm{mg}$ DNA for control, $10 \mu \mathrm{M}, 20 \mu \mathrm{M}$, and $30 \mu \mathrm{M}$ CQ-treated groups, respectively. Bars represent means \pm SEM of 17-23 samples from three replicate experiments. The pattern legend in panel $\mathrm{C}$ applies throughout the figure. Key: $\left({ }^{*}\right) \mathrm{P}<0.05$, and $\left(^{* *}\right) \mathrm{P}<0.001$ (Scheffe multiple comparison test).

VYS were much greater overall than those observed in the embryo proper (mean $=269 \mathrm{mU} / \mathrm{mg}$ DNA for control VYSs vs $4 \mathrm{mU} / \mathrm{mg}$ DNA for control embryos) when measured at the end of the culture period. Twenty-six-hour exposure of conceptuses to embryotoxic concentrations of $\mathrm{CQ}(10-30 \mu \mathrm{M})$ enhanced the lysosomal cysteine proteinase activities in both embryos and VYSs of GD 11.5 conceptuses. The enhancement was greatest in embryonic tissues, where $30 \mu \mathrm{M} \mathrm{CQ}$ treatment increased activities to $803 \%$ of control $(32 \mathrm{mU} / \mathrm{mg}, \mathrm{P}<0.001)$. Although the absolute levels of enzyme activity in the VYS were much greater than those in the embryo proper, the CQ-induced enhancement of activity in the VYS was not as great: maximum activities in VYSs exposed to $20 \mu \mathrm{M} \mathrm{CQ}$ reached $385 \%$ of control when normalized to DNA content $(1035 \mathrm{mU} / \mathrm{mg}$, $P<0.001)$. Another difference in the $C Q$-induced enhancement of cathepsin activity observed between embryos and VYSs was in the concentrationresponse relationship. While $\mathrm{CQ}$ treatment caused a concentration-dependent increase in enzyme activity in the embryo proper that peaked in conceptuses exposed to $30 \mu \mathrm{M} \mathrm{CQ}$, the peak activity in the VYS occurred in conceptuses exposed to $20 \mu \mathrm{M} \mathrm{CQ}$ and decreased to $106 \%$ of control in the $30 \mu \mathrm{M}$ group $(286 \mathrm{mU} / \mathrm{mg}$, not statistically significant).

Further experiments were performed to characterize the CQ-induced enhancement of cathepsin $B$ and $L$ activity in conceptal tissues. These experiments included evaluation of various exposure times and concentrations of $\mathrm{CQ}$ and related lysosomotropic compounds, as well as the use of specific inhibitors to verify lysosomal cysteine proteinase activity. Figure 2 shows a $30 \%$ decrease in the specific activity of cathepsin B and L between GD 10.5 and GD 11.5 in control VYSs of conceptuses grown in vitro. This is a consistent finding that has also been observed in freshly explanted tissue (data not shown). In VYSs of conceptuses exposed to minimally embryotoxic concentrations of CQ or PRIM for $2 \mathrm{hr}$ on GD 10, no significant change in enzyme activity occurred compared with concurrent controls, whereas 24-hr exposure elicited significantly enhanced activity $(240 \%$ of control, $P<0.001$ and $170 \%$ of control, $P<0.05$ for $C Q$ and PRIM, respectively). This enhanced activity produced by 
A .

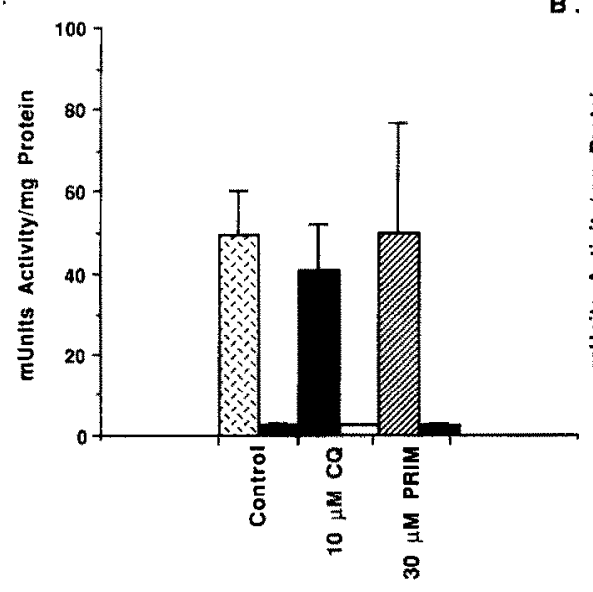

B.

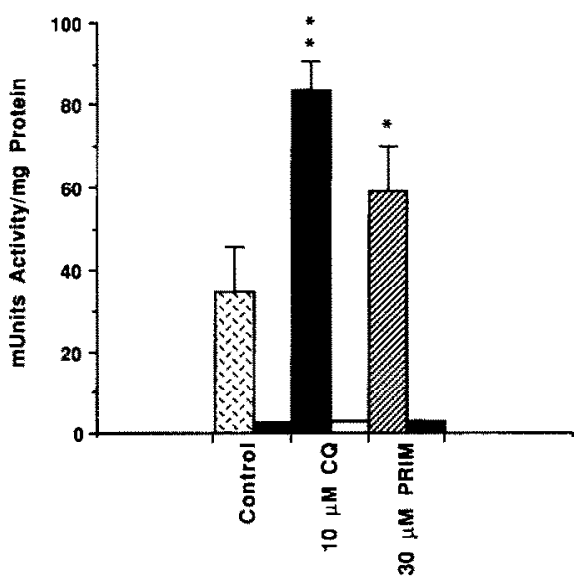

Fig. 2. Characterization of enhanced VYS cathepsin B and L activity in conceptuses exposed to lysosomotropic weak bases. Bars represent means $\pm \mathrm{SD}$ of $\mathrm{N}=4$ samples from one experiment. (A) Activity in VYS homogenates from GD 10.5 conceptuses exposed to minimally embryotoxic concentrations of either chloroquine (CQ) or primaquine (PRIM) for $2 \mathrm{hr}$. Cysteine proteinase activity is confirmed in the right-hand column of each group by inhibition with $1 \mu \mathrm{M} \mathrm{Z}$-Phe-Ala-CHN ${ }_{2}(5-m i n$ pretreatment at $37^{\circ}$ ). (B) Activity in VYS homogenates from GD 11.5 conceptuses grown for $26 \mathrm{hr}$ in the same medium as used in "A." As in "A," the right-hand column of each group was inhibited with $1 \mu \mathrm{M}$ Z-Phe-Ala-CHN 2 . Key: $\left(^{*}\right) \mathrm{P}<0.05$, and $\left(^{*}\right) \mathrm{P}<0.01$ (Scheffe multiple comparison test).

A.

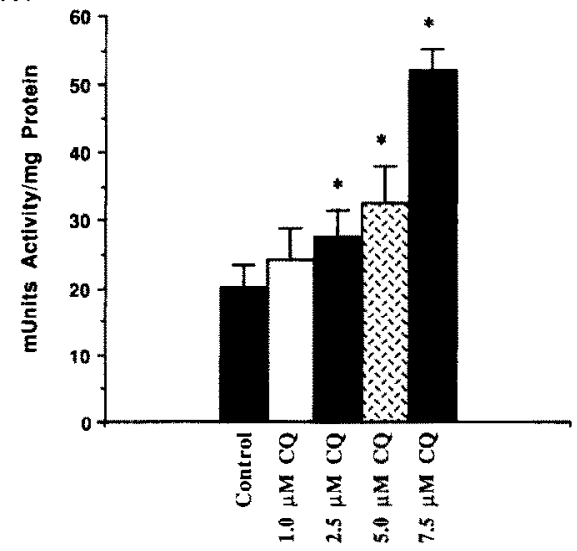

B.

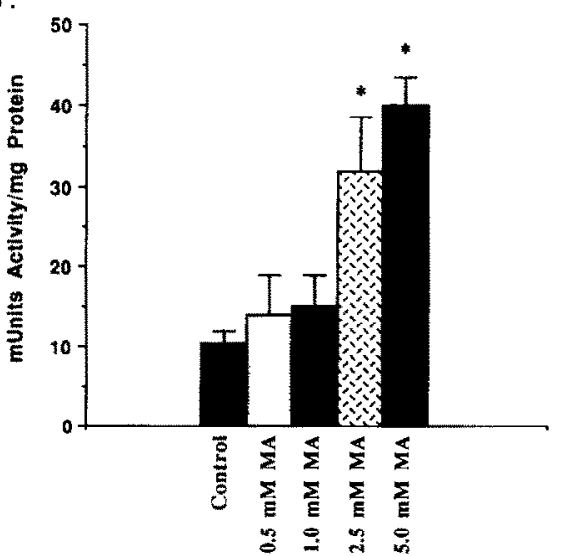

Fig. 3. Effect of low concentrations of lysosomotropic amines on VYS cathepsin B and L activity. Cultured rat conceptuses (GD 10.5 to 11.5 ) were exposed for $26 \mathrm{hr}$ to concentrations of less than $10 \mu \mathrm{M}$ $\mathrm{CQ}(\mathrm{A})$ or less than $6 \mathrm{mM} \mathrm{MA}(\mathrm{B})$. Bars represent means \pm SD of 4-8 samples from two replicate experiments (A) and 3-6 samples from one experiment (B). Key: (*) $P<0.05$ (Scheffe multiple comparison test).

$\mathrm{CQ}$ and PRIM treatment was found to be sensitive to inhibition by low micromolar concentrations of specific cysteine proteinase inhibitors such as Z-PheAla-CHN 2 (Fig. 2). Compound E-64 was also extremely effective, inhibiting control and CQenhanced activities nearly $100 \%$ at $5 \mu \mathrm{M}$ concentrations (data not shown). These data indicate that the CQ-induced enhancement of cathepsin activity was not artifactual. Figure 3 illustrates that a 26-hr exposure to non-embryotoxic concentrations of $\mathrm{CQ}$ (below $10 \mu \mathrm{M}$ ) enhanced cathepsin B and L activity in VYSs in a concentration-dependent fashion. This was also true of MA, another lysosomotropic amine (Fig. 3B). The concentrations of PRIM and MA used in Figs. 2 and 3 showed little toxicity and did not affect VYS protein content. These data are therefore shown normalized to protein content.

In Fig. 4 we see the effect of exposure time on cathepsin $B$ and $L$ activity and protein content of conceptuses treated with $20 \mu \mathrm{M}$ CQ. The CQinduced increases in enzyme activity were detectable 

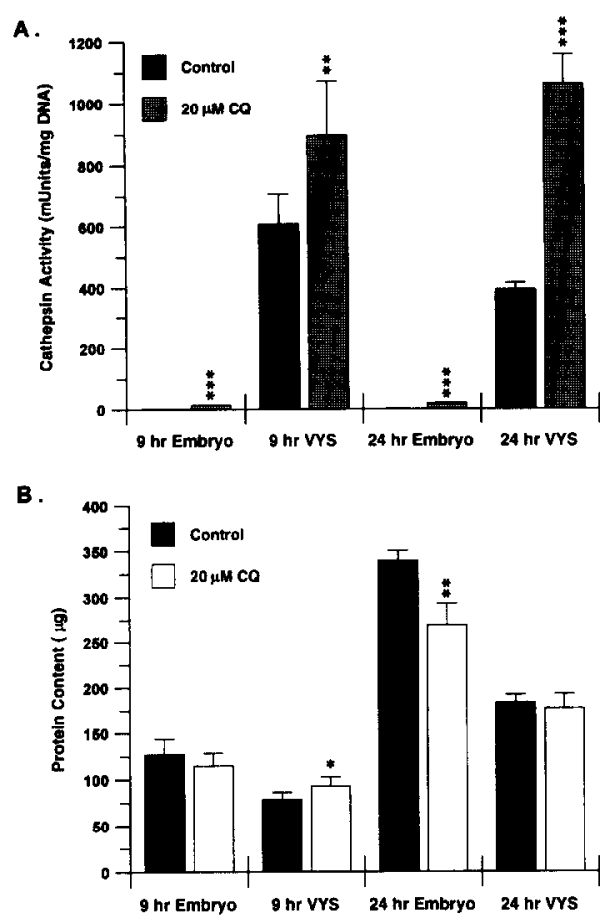

Fig. 4. Lysosomal cysteine proteinase activity (A) and protein content (B) of organogenesis-stage conceptuses exposed to $20 \mu \mathrm{M} \mathrm{CQ}$ for 9 or $24 \mathrm{hr}$. Mean embryonic enzyme activities were 2.7 (control) and $14.1(20 \mu \mathrm{M} \mathrm{CQ}$ ) $\mathrm{mU} / \mathrm{mg}$ DNA after a 9-hr incubation on GD 10.5; and 2.0 (control) and $19.3(20 \mu \mathrm{M} \mathrm{CQ}) \mathrm{mU} / \mathrm{mg}$ DNA after a 24 $\mathrm{hr}$ incubation on GD 11.5. Bars represent means $\pm \mathrm{SD}$ of 4 samples from one experiment. Key: $\left({ }^{*}\right) \mathrm{P}<0.05,\left({ }^{* *}\right)$ $\mathrm{P}<0.01,\left({ }^{* * *}\right) \mathrm{P}<0.001$ ( $t$-test $)$.

after $9 \mathrm{hr}$ of treatment in both embryos and VYSs, although the magnitude of the increase was much less than that observed after $24 \mathrm{hr}$ (VYS activity was increased by $48 \%$ after $9 \mathrm{hr}, \mathrm{P}<0.01$, vs a $170 \%$ increase after $24 \mathrm{hr}, \mathrm{P}<0.001$ ). Interestingly, $20 \mu \mathrm{M}$ CQ treatment elicited an increase in VYS protein content after $9 \mathrm{hr}(118 \%$ of control, $\mathrm{P}<0.05)$ that was not observed after $24 \mathrm{hr}$ of treatment ( $96 \%$ of control, not significant).

The effect of CQ treatment on VYS function in cultured conceptuses was evaluated further by determinations of fluid-phase pinocytosis. Uptake of FITC-dextran was measured during several periods between GD 10 and GD 11 in embryo culture. Conceptuses exposed to FITC-dextran accumulated FITC fluorescence only in the VYS and not the embryo proper, which is characteristic of fluid-phase uptake in whole conceptuses (data not shown). Uptake of FITC-dextran by the VYSs was linear for at least $5 \mathrm{hr}$ in GD 10.5 conceptuses (Fig. 5). Linearity was also observed under similar conditions in day 11.5 conceptuses (data not shown). One-hour pretreatment of GD 10.5 conceptuses with $30 \mu \mathrm{M} \mathrm{CQ}$, followed by a 4-hr exposure to the FITCdextran in the presence of $30 \mu \mathrm{M} \mathrm{CQ}$, inhibited the accumulation of FITC fluorescence in VYSs by approximately $35 \% \quad(\mathrm{P}<0.05)$. Table 2 lists

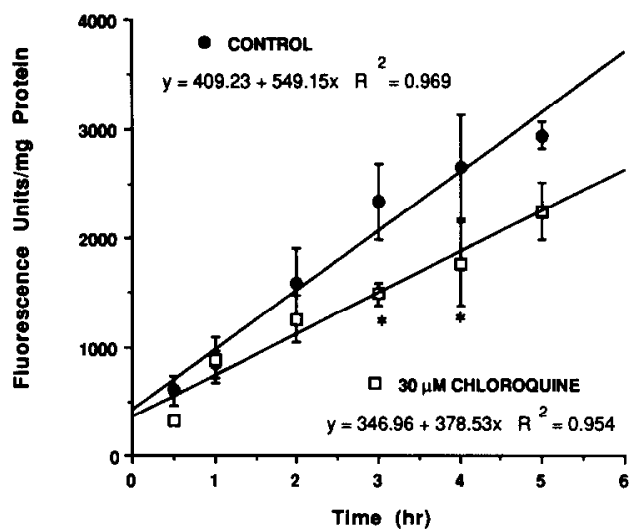

Fig. 5. Effect of chloroquine on fluid-phase pinocytosis in GD 10.5 VYSs. Points represent means \pm SD of 3-6 samples from three experiments. Key: $\left(^{*}\right) \mathrm{P}<0.05$ ( $t$-test).

Table 2. Effect of chloroquine on VYS fluid-phase pinocytosis in rat conceptuses in vitro*

\begin{tabular}{lc}
\hline & $\begin{array}{c}\text { Endocytic Index } \\
(\mu \mathrm{L} / \mathrm{mg} / \mathrm{hr})\end{array}$ \\
\hline 8-hr Treatment & \\
GD 10.5 control (8) & $3.4 \pm 0.5$ \\
$10 \mu \mathrm{M} \mathrm{CQ}(7)$ & $3.7 \pm 0.6$ \\
$20 \mu \mathrm{M} \mathrm{CQ}(8)$ & $3.3 \pm 0.7$ \\
$30 \mu \mathrm{M} \mathrm{CQ}(8)$ & $2.1 \pm 0.9 \dagger$ \\
24-hr Treatment & \\
GD 11.5 control (15) & $2.8 \pm 0.3$ \\
$10 \mu \mathrm{M} \mathrm{CQ} \mathrm{(15)}$ & $3.1 \pm 0.4$ \\
$20 \mu \mathrm{M}$ CQ (15) & $2.5 \pm 0.3$ \\
$30 \mu \mathrm{M} \mathrm{CQ} \mathrm{(6)}$ & $1.8 \pm 0.2 \ddagger$ \\
\hline
\end{tabular}

${ }^{*}$ Chloroquine and $40 \mathrm{kDa}$ FIIC-dextran were added simultaneously to the culture medium and incubated for the time indicated. The Endocytic Index was calculated by the method of Williams et al. [35], and represents the mean $\pm \mathrm{SD}$ of $(\mathrm{N})$ yolk sacs taken at the time indicated.

$\dagger, \ddagger$ Significantly different from control; $\dagger \mathrm{P}<0.01$ and $\$ \mathrm{P}<0.001$ (Scheffe multiple comparison test).

Endocytic Indices calculated from the uptake of FITC-dextran by VYSs. The highly embryotoxic concentration of $30 \mu \mathrm{M} C Q$ was again observed to inhibit VYS fluid-phase pinocytosis, as evidenced by the decreased Endocytic Index (60\% of control after $8 \mathrm{hr}, \mathrm{P}<0.01 ; 66 \%$ of control after $24 \mathrm{hr} ; \mathrm{P}<0.001)$. Lower concentrations of $\mathrm{CQ}$ caused small changes in the Endocytic Index, which were not statistically significant. Because these data (like enzyme activity) are normalized to protein content, these decreases in fluid-phase pinocytosis can be attributed largely to the increased VYS protein content produced by $30 \mu \mathrm{M}$ CQ treatment. We are currently unable to normalize these data to DNA content because fluorescein interferes with our DNA determination method. The protein content in VYSs exposed to $30 \mu \mathrm{M}$ CQ was consistently higher than in control 
VYSs by $20-25 \%$, and thus any true decreases in fluid-phase uptake by $\mathrm{CQ}$ are small (15\% or less).

\section{DISCUSSION}

The theory of lysosomotropism, as proposed by de Duve et al. [8], states that weak bases such as $\mathrm{CQ}$ can accumulate in acidic cellular compartments by virtue of their physico-chemical properties. These authors determined that cellular CQ concentrations could rapidly reach $10 \mathrm{mM}$ when rat fibroblasts were exposed to culture medium containing $100 \mu \mathrm{M} C \Omega$. It is presumed that the concentration of the drug in the lysosomes is even greater. The data presented here illustrate that a similar phenomenon occurred when rat conceptuses were exposed to $\mathrm{CQ}$ during whole embryo culture. Conceptuses were found to accumulate high concentrations of the drug within their tissues relatively early in the culture period, and concentrations determined at the end of the culture period were also high. These findings suggest that $\mathrm{CQ}$ concentrations in conceptal tissues reach an apparent steady state rapidly, as has been observed in cell culture experiments [14]. The VYS attains much higher concentrations of $\mathrm{CQ}$ than the embryo proper, which seems reasonable considering the extensive vacuolar system of the VYS endoderm epithelium and its direct exposure to the culture medium.

High concentrations of $\mathrm{CQ}$ can alter the lysosomal milieu and lead to a condition resembling "lysosomal storage disease," in which the lysosomes accumulate macromolecules which are otherwise normally degraded and removed [36]. We have found that exposure of rat conceptuses to highly embryotoxic concentrations of $\mathrm{CQ}(30 \mu \mathrm{M})$ increases the protein content of the VYS, and this increased protein most likely accumulates within lysosomes of the VYS endoderm [5]. These data suggest that $\mathrm{CQ}$ acts similar to other protease inhibitors such as leupeptin, resulting in accumulation of protein in the VYS epithelium [23]. Although the VYSs of conceptuses exposed to lower concentrations of $\mathrm{CQ}$ that are still embryotoxic ( 10 and $20 \mu \mathrm{M}$ ) did not exhibit increased protein content at the end of the culture period, increases in VYS protein content could be detected at intermediate time points. This observation would argue for a transient inhibition of VYS proteolysis by $\mathrm{CQ}$ that is sufficient to cause embryotoxicity.

In light of these observations, our current data may appear contradictory by showing an increase, rather than a decrease, in lysosomal proteinase activity (Figs. 1-4). Our hypothesis states that $\mathrm{CQ}$ inhibits conceptal proteolysis reversibly in situ via increased lysosomal $\mathrm{pH}$ or osmotic effects as described previously. Once the tissue is homogenized and diluted in assay buffer under conditions for determination of optimal activity, we would no longer expect $\mathrm{CQ}$ to inhibit the enzymes. Thus, the increases in cathepsin $\mathrm{B}$ and $\mathrm{I}$. activity observed in vitro following conceptal exposure to $\mathrm{CQ}$ likely represent a compensatory increase in enzyme activity. It seems reasonable that in conceptuses exposed to nonembryotoxic concentrations of $\mathrm{CQ}$ (less than $10 \mu \mathrm{M}$ ), the increased cathepsin $B$ and $L$ activity is sufficient to compensate for the inhibitory effects of CQ. However, once the medium concentration of $\mathrm{CQ}$ reaches $10 \mu \mathrm{M}$, increased VYS cysteine proteinase activity can no longer compensate fully for the altered lysosomal milieu, and embryotoxicity results. Because increases in enzyme activity occur relatively slowly compared with the accumulation of $\mathrm{CQ}$ in conceptal tissues, there also appears to be a period of time during which VYS proteolysis is likely to remain interrupted by $\mathrm{CQ}$ treatment.

A model of reversible inhibition and compensatory increase in proteolytic activity is supported by reports in the literature. The ability of $\mathrm{CQ}$ to inhibit degradation of both endogenous and exogenous proteins has been well established $[12-17,37]$ and its inhibition of proteolysis in perfused rat kidney is readily reversible [38]. Moreover, long-term administration of reversible protease inhibitors has been shown previously to enhance lysosomal protease activity when measured in vitro $[39.40]$. At present, direct experimental evidence that $\mathrm{CQ}$ inhibits VYS proteolysis in situ in our system is lacking, but we are developing methods to assess this possibility.

Enhanced cathepsin $B$ and $L$ activity in conceptal homogenates indicates that treatment with $\mathrm{CQ}$ or related compounds either stimulates enzyme synthesis, inhibits enzyme turnover, or both. In this regard, Kominami et al. [41] have described increased content and half-life of cathepsin $B$ and $L$ in rat liver following in vivo administration of E-475 (an irreversible cysteine proteinase inhibitor), which was not blocked by cycloheximide. These authors suggest that lysosomal cysteine proteinases may be involved in their own degradation. However, increased proteolytic activity and autophagy have also been observed in several cell types as a response to amino acid withdrawal [reviewed in Ref. 42], indicating that regulatory synthetic mechanisms might also be available. Further experiments are required in order to distinguish between these possibilities in the rat conceptus.

Thirty micromolar $\mathrm{CQ}$ treatment maximally enhanced the cathepsin B and L activity measured in embryos, whereas that in VYSs was found to be no different than in the controls. This differential response can be attributed logically to the ability of the VYS to accumulate much higher concentrations of the drug than the embryo proper. The inability of $30 \mu \mathrm{M}$ CQ treatment to enhance VYS cathepsin $B$ and $L$ activity over control also represents a qualitative change in the action of $\mathrm{CQ}$ at this concentration which could result from several potential effects of the drug: (1) irreversible inhibition of the enzyme if lysosomal $\mathrm{pH}$ rises above 7 , since cathepsin $\mathrm{L}$ is inhibited irreversibly above neutral $\mathrm{pH}$ [43]; (2) direct inhibition of cathepsin $\mathrm{B}$ and $\mathrm{L}$ by high intralysosomal concentrations of $\mathrm{CQ}$. as has been observed for cathepsin $B$ in vitro [14]; (3) altered targeting of the enzymes to the lysosome (via the mannose-6-phosphate receptor), as occurs in CQ-treated fibroblasts [44]; and (4) inhibition of protein synthesis due to decreased intracellular amino acid pools as seen in several cell types $[37,45]$.

In addition to alterations in lysosomal hydrolytic capacity, the effects of $\mathrm{CQ}$ on mammalian cells include changes in endocytotic capacity. Reduced 
VYS pinocytosis has been reported previously after exposure of cultured GD 17.5 VYSs to higher concentrations of CQ than those used in the present study [17]. Our data indicate that VYS fluid-phase pinocytosis is diminished in CQ-treated conceptuses at concentrations that are highly embryotoxic $(30 \mu \mathrm{M})$, but much of this effect can be attributed to the normalization of these data to increased VYS protein content. It therefore appears that reduced fluid-phase pinocytosis in the VYS may contribute to the embryotoxicity of $\mathrm{CQ}$ only at concentrations of $30 \mu \mathrm{M}$ or greater, and not at lower, but still embryotoxic concentrations. This does not exclude the possibility that CQ may inhibit receptor-mediated endocytosis or other forms of uptake in the rat conceptus.

Besides inhibition of VYS nutritional function, CQ embryntoxicity could result from several other effects of the drug on cell function. For instance, relatively low concentrations of CQ can inhibit DNA synthesis in certain cell culture systems [46]. According to Krogstad and Schlesinger [9], inhibition of DNA polymerase requires $\mathrm{CQ}$ concentrations of 1-2 $\mathrm{mM}$. Thus, the CQ concentrations that we have estimated in conceptal tissues appear high enough to inhibit DNA synthesis in the VYS, but most likely not the embryo proper. Although we assume that most of the drug is localized in the vacuolar system, we cannot currently estimate $\mathrm{CQ}$ concentrations in the nucleus and so can only speculate that $\mathrm{CQ}$ may inhibit DNA synthesis in the VYSs of exposed conceptuses. Despite this possibility, the most likely explanantion for the in vitro embryotoxicity of $\mathrm{CQ}$ which we have obseved is that CQ alters the lysosomal processing for proteins by the VYS, resulting in a diminished amino acid supply for both the VYS and embryo.

In conclusion, the current data show that CQinduced embryotoxicity is associated with the accumulation of high concentrations of the drug in conceptal tissues and changes in the protein content and activity of lysosomal cysteine proteinases in these tissues. In contrast, inhibition of VYS fluidphase pinocytosis by $\mathrm{CQ}$ cannot be detected until conceptal viability begins to be affected $(30 \mu \mathrm{MCQ})$. The increased enzyme activity we observed occurs as a general response of conceptuses to lysosomotropic amines, and can be detected after exposure to nonembryotoxic concentrations of these compounds. This suggests that increased lysosomal cysteine proteinase activity is a compensatory response of organogenesis-stage rat conceptuses to such compounds, and measurement of this activity may be useful as an indicator of conceptal exposure to agents that alter lysosomal function.

Acknowledgements-The authors wish to thank Sara Carlson, Roongrudee Hiranruengchok and Bjorn Thorsrud for their technical assistance; and Dr. Tammy McNutt for editing assistance. This work was supported by NIH Grants ES 05235 and ES 07062 and by the March of Dimes Birth Defects Foundation Grant 15-179.

\section{REFERENCES}

1. Udalova LD, Effect of khingamin (chloroquine diphosphate, aralen) on the embryonal development in rats. Russ Pharmacol Toxicol 30: 114-117, 1967.

2. Sharma $A$ and Rawat $A K$, Toxicological consequences of chloroquine and ethanol on the developing fetus. Pharmacol Biochem Behav 34: 77-82, 1989.

3. Landauer $W$, Cholinomimetic teratogens. VI. The interaction of cholinomimetic teratogens with the antimalarial drugs chloroquine and chlorguanide. Teratology 17: 335-340, 1978.

4. Hart CW and Naunton RF, The ototoxicity of chloroquine phosphate. Arch Otolaryngol 80: 407-412, 1964.

5. Ambroso JL and Harris C, Chloroquine embryotoxicity in the postimplantation rat conceptus in vitro. Teratology 48: 213-226, 1993.

6. Yielding LW, Riley TL and Yielding KL, Preliminary study of caffeine and chloroquine enhancement of Xray induced birth defects. Biochem Biophys Res Commun 68: 1356-1361, 1976.

7. Cohen SN and Yielding KL, Inlibition of DNA and RNA polymerase reactions by chloroquine. Proc Natl Acad Sci USA 54: 521-527, 1965.

8. de Duve C, de Barsy T, Poole B, Trouet A, Tulkens $P$ and Van Hoof F, Lysosomotropic agents. Biochem Pharmacol 23: 2495-2531, 1974.

9. Krogstad DJ and Schlesinger PH, A perspective on antimalarial action: Effects of weak bases on Plasmodium falciparum. Biochem Pharmacol 35: 547$552,1986$.

10. Ohkuma $S$ and Poole B, Fluorescence probe measurement of the intralysosomal $\mathrm{pH}$ in living cells and the perturbation of $\mathrm{pH}$ by various agents. Proc Natl Acad Sci USA 75: 3327-3331, 1978.

11. Sorokin LM, Morgan EH and Yeoh GCT, Transferrin endocytosis and iron uptake in developing myogenic cells in cuiture: Effects of microtubular and metabolic inhibitors, sulphydryl reagents and lysosomotrophic agents. I Cell Physiol 137: 483-489, 1988.

12. Shimizu $A$ and Kawashima S, Kinetic study of internalization and degradation of ${ }^{131}$ I-labeled folliclestimulating hormone in mouse sertoli cells and its relevance to other systems. I Biol Chem 264: 13632$13638,1989$.

13. Kaiser N, Tur-Sinai $A$, Hasin $M$ and Cerasi E, Binding, degradation, and biological activity of insulin in vascular smooth muscle cells. Am J Physiol 249: E292-E298, 1985.

14. Wibo $\mathrm{M}$ and Poole $\mathrm{B}$, Protein degradation in cultured cells. II. The uptake of chloroquine by rat fibroblasts and the inhibition of cellular protein degradation and cathepsin $B_{1}$. I Cell Biol 63: 430-440, 1974.

15. Posner BI, Patel BA, Khan MN and Bergeron JJM, Effect of chloroquine on the internalization of ${ }^{125} \mathrm{I}$ insulin into subcellular fractions of rat liver. $J$ Biol Chem 257: 5789-5799, 1982.

16. King $A C$, Hernaez-Davis $L$ and Cuatrecasas $P$, Lysomotropic amines cause intracellular accumulation of receptors for epidermal growth factor. Proc Natl Acid Sci USA 77; 3283-3287, 1980.

17. Livesy G, Williams KE, Knowles SE and Ballard FJ, Effects of weak bases on the degradation of endogenous and exogenous proteins by rat yolk sacs. Biochem $J$ 188: 895-903, 1980.

18. Freeman SJ, Beck F and Lloyd JB, The role of the visceral yolk sac in mediating protein utilization by rat embryos cultured in vitro. $J$ Embryol Exp Morphol 66: 223-234, 1981.

19. Freeman SJ and Lloyd JB, Evidence that protein ingested by the rat visceral yolk sac yields amino acids for the synthesis of embryonic protein. $J$ Embryol Exp Morphol 73: 307-315, 1983.

20. Lloyd JB, Cell physiology of the rat visceral yolk sac: 
A study of pinocytosis and lysosome function. Teratology 41: 383-393, 1990.

21. Williams KE, Lloyd JB, Davies $M$ and Beck F, Digestion of an exogenous protein by rat yolk sac cultured in vitro. Biochem J 125: 303-308, 1971.

22. Knowles SE and Ballard FJ, Effects of microbial proteinase inhibitors on the degradation of endogcnous and internalized proteins by rat yolk sacs. Biochem $J$ 196: $41-48,1981$.

23. Freeman SJ and Lloyd JB, Inhibition of proteolysis in rat yolk sac as a cause of teratogenesis. Effects of leupeptin in vitro and in vivo. J Embryol Exp Morphol 78: 183-193, 1983.

24. Bradford MM, A rapid and sensitive method for quantitation of microgram quantities of protein using the principal of protein-dye binding. Anal Biochem 72: 248-254, 1976

25. Stark KL, Harris $C$ and Juchau MR, Influence of electrophilic character and glutathione depletion on chemical dysmorphogenesis in cultured rat embryos. Biochem Pharmacol 38: 2685-2692, 1989.

26. Labarca $L$ and Paigen $K$, A simple, rapid and sensitive DNA assay procedure. Anal Biochem 102: 344-352. 1980.

27. Adelusi SA and Salako LA, Improved fluorimetric assay of chloroquine in biological samples. $J$ Pharm Pharmacol 32: 71-72, 1980.

28. Barrett AJ and Kirschke H, Cathepsin B, cathepsin H and cathepsin L. Methods Enzymol 80: 535-561, 1981.

29. Daston GP, Baines D. Yonker JE and LehmanMckeeman LD, Effects of lysosomal proteinase inhibition on the development of the rat embryo in vitro. Teratology 43: 253-261. 1991.

30. Rich DH, Inhibitors of cysteine proteinases. In: Proteinase Inhibitors (Eds. Barrett AJ and Salveson G), pp. 158-164. Elsevier Science Publishers, Amsterdam, 1986.

31. Grubb JD, Koszalk TR, Drabick JJ and Metrione RM, The activities of thiol proteases in the rat visceral yolk sac during late gestation. Placenta 12: 143-151, 1991.

32. Berlin RD and Oliver JM, Surface functions during mitosis. II. Quantitation of pinocytosis and kinetic characterization of the mitotic cycle with a new fluorescence technique. J Cell Biol 85: 660-671, 1980.

33. Bar-Sagi D and Feramisco JR, Induction of membrane ruffling and fluid-phase pinocytosis in quiescent fibroblasts by ras proteins. Science 233: 1061-1068, 1986.
34. Duncan R and Lloyd JB, Pinocytosis in the rat visceral yolk sac. Effects of temperature, metabolic inhibitors and some other modifiers. Biochim Biophys Acta 544: $647-655,1978$

35. Williams KE, Kidston EM, Beck $F$ and Lloyd JB, Quantitative studies of pinocytosis. I. Kinetics of uptake of $\left[{ }^{125} \mathrm{I}\right]$ polyvinylpyrrolidone by rat yolk sac cultures in vitro. J Cell Biol 64: 113-122, 1975.

36. Lie SO and Schofield B, Inactivation of lysosomal function in normal cultured human fibroblasts by chloroquine. Biochem Pharmacol 22: 3109-3114, 1973.

37. Seglen PO and Gordon PB, Effects of lysosomotropic amines, diamines, amino alcohols, and other amino compounds on protein degradation and protein synthesis in isolated rat hepatocytes. Mol Pharmacol 18: 468-475, 1980.

38. Wall DA and Maack T. Endocytic uptake, transport, and catabolism of proteins by eptithelial cells. $A m J$ Physiol 248: C12-C20, 1985.

39. Gerard KW. Hipkiss AR and Schneider DL, Degradation of intracellular protein in muscle. Lysosomal response to modified proteins and chloroquine. $J$ Biol Chem 263: 18886-18890, 1988.

40. Tanaka K, Ikegaki N and Ichihara A, Purification and characterization of hemoglobin-hydrolyzing acidic thiol protease induced by leupeptin in rat liver. J Biol Chem 259: 5937-5944, 1984.

41. Kominami E, Tsukahara T, Bando $Y$ and Katunuma $\mathrm{N}$, Autodegradation of lysosomal cysteine proteinases. Biochem Biophys Res Commun 144: 749-756, 1987.

42. Mortimore GE, Mechanism and regulation of induced and basal protein degradation in liver. In: Lysosomes. Their Role in Protein Breakdown (Eds. Glaumann H and Ballard FJ), pp. 415-443. Academic Press, London, 1987.

43. Barrett AJ, Cathepsin B and other thiol proteinases. In: Proteinases in Mammalian Cells and Tissues (Ed. Barrett AJ), pp. 181-208. North-Holland, Amsterdam, 1977.

44. Gonzalez-Noriega A, Grubb JH. Talkad V and Sly WS. Chloroquine inhibits lysosomal enzyme pinocytosis and enhances lysosomal enzyme secretion by impairing receptor recycling. J Cell Biol 85: 839-852, 1980.

45. Scornik $O A$, Effects of inhibitors of protein degradation on the rate of protein synthesis in Chinese hamseter ovary cells. J Cell Physiol 121: 257-262, 1984.

46. Pazmino NH, Yuhas JM and Tennant RW, Inhibition of murine RNA tumor virus replication and oncogenesis by chloroquine. Int J Cancer 14: 379-385, 1974. 